\title{
MOLECULAR CHARACTERIZATION OF ELEPHANTGRASS ACCESSIONS THROUGH RAPD MARKERS
}

\author{
Caracterização molecular de acessos de capim-elefante utilizando marcadores RAPD
}

\author{
Leônidas Paixão Passos ${ }^{1}$, Marco Antonio Machado ${ }^{2}$, Maria Coletta Vidigal ${ }^{3}$, Ana Lúcia Campos ${ }^{4}$
}

\begin{abstract}
Elephantgrass pastures are limited by yield variations and reductions in forage quality and availability, thus making the search for genotypes with reduced seasonality a major concern. In order to verify the extent of genetic variability among contrasting cultivars, ten elephantgrass accessions were analyzed through DNA amplification by RAPD technique. A total of 160 DNA bands were generated with the use of 44 random primers and $23 \%$ of these bands were monomorphic for all accessions. Gel-obtained binary data (1 for presence and 0 for absence) were used for generating a genetic distance matrix, which was utilized in a UPGMA grouping analysis. Elephantgrass cultivars Cameroon and Vruckwona were the accessions mostly divergent from the others, with an average genetic distance of 0.34 . The accessions with the lowest average genetic distances from the others were Pioneiro and CNPGL 27-5, both with a distance of 0.25 . Overall, genetic distances ranged from 0.06 to 0.43 , indicating little genetic variability for the set of accessions, despite the contrasting morphology of the studied genotypes.
\end{abstract}

Index terms: molecular markers, elephantgrass, RAPD, DNA.

\begin{abstract}
RESUMO
O cultivo do capim-elefante é limitado por variações na produção de biomassa e por reduções na qualidade e disponibilidade de forragem, tornando prioritária a busca de genótipos com menor sazonalidade de produção. Para verificar a extensão da variabilidade genética entre cultivares contrastantes, 10 acessos foram analisados via amplificação do DNA pela técnica RAPD. Foram utilizados 44 primers aleatórios, que produziram um total de 160 bandas de DNA, sendo que 23\% das bandas analisadas foram monomórficas para todos os acessos. Os dados binários, originados dos géis (1-presença, 0-ausência), foram utilizados para gerar uma matriz de distâncias genéticas, que foi utilizada para uma análise de agrupamento segundo o método da média das distâncias (UPGMA). Os acessos mais divergentes dos demais foram Cameroon e Vruckwona, com distâncias genéticas médias de 0,34 . Os acessos com menores distâncias genéticas médias dos demais foram Pioneiro e CNPGL 27-5, ambos com uma distância genética média de 0,25. As distâncias genéticas, considerando todas as análises, variaram de 0,06 a 0,43 , indicando uma variabilidade genética pouco acentuada, embora os acessos estudados sejam bastante contrastantes em relação à morfologia e fisiologia.
\end{abstract}

Termos para indexação: Marcadores moleculares, Capim-Elefante, RAPD, DNA.

(Recebido para publicação em 16 de janeiro de 2004 e aprovado em 17 de agosto de 2004)

INTRODUCTION

Elephantgrass (Pennisetum purpureum Schum.) is an important forage crop for dairy production systems in the tropics. However, yield fluctuations during the growth season and sharp drops in forage quality and availability during the dry season render the species low in agronomic effectiveness to farmers (PASSOS, 1999). Therefore, the search for genotypes exhibiting reduced seasonality in forage production and improved forage quality becomes of paramount importance for improving elephantgrass-based dairy production systems.
There is substantial agronomic and morphological diversity in elephantgrass germplasm (XAVIER et al., 1995), generally preserved through the occurrence of protogyny, which favors crossfertilization, and through the predominance of vegetative propagation. The germplasm is highly heterozygous and heterogeneous, suggesting the existence of a large amount of genetic variability within the species (HANNA, 1999). However, since the species is an allotetraploid $(2 \mathrm{n}=4 \mathrm{x}=28)$ with the A and B genomes (PEREIRA et al., 2001), alternative procedures should be sought to better characterize genetic variability of germplasm.

\footnotetext{
1. Engenheiro Agrônomo, Ph.D., Embrapa Gado de Leite - National Dairy Cattle Research Center - Rua Eugênio do Nascimento 610 - Juiz de Fora, MG 36038-330 - Brasil - Ipassos@cnpgl.embrapa.br

2. Engenheiro Agrônomo, Ph.D. - Embrapa Gado de Leite.

3. Bioquímica, M.S. - Embrapa Gado de Leite.

4. Bióloga, B.S. - Embrapa Gado de Leite.
} 
In recent years, fingerprinting systems based on RAPD analysis have been increasingly utilized for detecting genetic polymorphism in several plant genera. The most common uses of the technique for scientific and commercial purposes include the discrimination among species for post-harvest purposes (HOSOKAWA et al., 2000), identification of crop cultivars to settle lawsuits (CONGIU et al., 2000), marker assisted selection establishment of phylogenetic position of natural populations (SGORBATI et al., 2004; TSUJI \& OHNISHI, 2001; VICCINI et al., 2004), certification of lack of polymorphism between in vitro and conventionally propagated plant stands (HAO et al., 2004; LAIA et al., 2000; SALVI et al., 2002), and determination of genetic variation in wild and cultivated populations (BIRMETA et al., 2004; GUSTAFSON et al., 1999; SONNANTE et al., 2002).

Few attempts have been carried out to understand genetic variability of elephantgrass based on analyses of genomic DNA. Smith et al. (1989) verified the existence of polymorphism in different populations of elephantgrass through RFLP procedure. Subsequently, RFLP markers were utilized to show genetic uniformity in plants derived from somatic embryos (SHENOY \& VASIL, 1992). However, those reports fell short of providing quantification of genetic variability within species, specially regarding genetic distances. Evaluations based on RAPD profiles would be suitable for providing such information due to the high level of polymorphism of this technique.

The purpose of this study was to verify the genetic diversity among morphologically contrasting elephantgrass accessions through DNA amplification patterns obtained by RAPD procedure.

\section{MATERIALS AND METHODS}

Plant materials: The following elephantgrass accessions were chosen, according to their morphological distinctiveness as reported by Xavier et al. (1995): Cameroon, Vruckwona, Napier, Mercker comum, Teresópolis, Mineiro, Mott, Pioneiro, CNPGL 27-5, and Roxo Anão (Dwarf Purple). Young leaves from each access were collected as source of DNA.

DNA Extraction: Collected samples, consisting of $300 \mathrm{mg}$ of fresh expanding leaf blade tissue, were immediately placed in labeled plastic bags, immersed in liquid $\mathrm{N} 2$, and maintained at $-80^{\circ} \mathrm{C}$ until use. Subsequently, each sample was reduced to a fine powder through mortar and pestles, with liquid N2 addition, and transferred to a $2.0 \mathrm{~mL}$ microcentrifuge tube. DNA extraction was performed using a modified CTAB procedure (FERREIRA \& GRATTAPAGLIA, 1995). Sample DNA concentration was estimated by comparing band patterns to lambda DNA standards in agarose gels and also by spectrophotometric absorbance at $260 \mathrm{~nm}$.

DNA amplification: Amplification reactions were conducted with a total volume of $20 \mu \mathrm{L}$, containing $0.4 \mu \mathrm{M}$ primer; $0.2 \mathrm{mM}$ dNTPs; 1.0 unit of Taq polymerase; $10 \mathrm{mM}$ Tris- $\mathrm{HCl}(\mathrm{pH} 8,0) ; 1.5 \mathrm{mM}$ $\mathrm{MgCl}_{2}$; and $50 \mathrm{mM} \mathrm{KCl}$. The following cycles of amplification were utilized: 40 cycles including sequential sample exposition to $94^{\circ} \mathrm{C}$ for $30 \mathrm{sec}, 37^{\circ} \mathrm{C}$ for $60 \mathrm{sec}$ and $72^{\circ} \mathrm{C}$ for $30 \mathrm{sec}$, followed by a cycle of $72^{\circ} \mathrm{C}$, for $7 \mathrm{~min}$. Amplification reactions were performed in the GeneAmp 9600 thermalcycler (Applied Biosystems). A total of 44 random primers were selected from Operon Technologies: OPA01, OPA02, OPA03, OPA04, OPA05, OPA07, OPA08, OPA09, OPA10, OPA11, OPA12, OPA13, OPA14, OPA15, OPA16, OPA17, OPA18, OPA19, OPA20, OPAQ12, OPAR10, OPAR13, OPAR20, OPAX13, OPAZ04, OPB01, OPB02, OPB02, OPB03, OPB06, OPB07, ОРB09, OPB10, OPB11, OPB12, OPC02, OPM04, OPN04, OPN14, OPO14, OPQ04, OPR14, OPV10 and OPX11.

DNA electrophoresis: Amplified DNA fragments were loaded in an $1.5 \%$ agarose gel and submitted to electrophoresis for $3 \mathrm{~h}$. The gel was then immersed in a ethidium bromide solution, for $30 \mathrm{~min}$. DNA fragments were visualized under ultra-violet light and gel image was captured by the Eagle-Eye II photo documentation system (Stratagene Inc.), and the images stored as JPEG archives.

Gel scoring and data analysis: Gel images were acquired by RFLPScan software, sample lanes were defined, and DNA bands were marked. Following proper adjustments, bands were exported as " 1 " for presence and " 0 " for absence in a text file. Polymorphic Information Content (PIC) for each primer was obtained as:

$$
P_{j \text { locus }}=1-\sum_{i=1}^{2} P_{i j}^{2}
$$

where $p_{i j} 2$ is the frequency of the $i$ allele in the $j$ locus, 


$$
P_{k \text { primer }}=1-\sum_{i=1}^{2} \sum_{j=1}^{n} P_{i j k}^{2}
$$

and $p_{i j k}^{2}$ is the frequency of the $i$ allele in the $j$ locus of the $k$ primer.

From the binary data, a matrix of genetic distances was generated according to Nei \& Li (1979), and a cluster analysis was performed according to UPGMA method. Branch robustness of tree topology was evaluated using bootstrap resampling with 500 replicates. The calculations were performed with BOOD-P software (COELHO, 2003).

\section{RESULTS AND DISCUSSION}

The 44 random primers used yielded 160 DNA bands (i.e. an averaged 3.64 bands per primer). A representative primer result is shown in Figure 1, in which $23 \%$ of the bands were found to be monomorphic for the 10 elephantgrass accessions. Polymorphic markers including primer PIC and number of polymorphic bands are shown in Table 1 . As expected, PIC values showed a very high correlation with the number of polymorphic bands since each marker band is the result of a single amplified locus.

The binary data obtained from the eletrophoretic analysis of DNA amplification products was used to generate a matrix of genetic distances (Table 2).

Based on such analysis, the accessions mostly divergent from the others were Cameroon and Vruckwona, with an average genetic distance of 0.34 . The accessions with the lowest average genetic distances from the others were Pioneiro and CNPGL $27-5$, both with a distance of 0.25 . Overall, genetic distances ranged from 0.06 to 0.43 , indicating a small genetic variability despite the fact that these accessions are very contrasting relative to physiological and morphological attributes. It is possible, however, that the small number of accessions might have depressed the overall genetic variability.

The genetic distance coefficients were used to cluster the data using the algorithm of unweighted pair-group method with arithmetic averages (UPGMA) in a dendrogram (Figure 2). Accessions Cameroon and Vruckwona grouped close to each other as expected by their genetic distance (0.06) showed in Table 2.
TABLE 1 - Polymorphic Information Content and number of polymorphic bands for each RAPD primer.

\begin{tabular}{|c|c|c|}
\hline Primer & PIC & $\begin{array}{c}\text { Number of } \\
\text { polymorphic bands }\end{array}$ \\
\hline OPA11 & 0,32 & 1 \\
\hline OPB12 & 0,32 & 1 \\
\hline OPA08 & 0,42 & 1 \\
\hline OPN14 & 0,42 & 1 \\
\hline OPAQ12 & 0,48 & 1 \\
\hline OPB11 & 0,48 & 1 \\
\hline OPQ04 & 0,48 & 1 \\
\hline OPA01 & 0,50 & 1 \\
\hline OPA18 & 0,63 & 2 \\
\hline OPN04 & 0,63 & 2 \\
\hline OPA10 & 0,66 & 2 \\
\hline OPA19 & 0,69 & 2 \\
\hline ОРВ01 & 0,70 & 2 \\
\hline OPV10 & 0,70 & 2 \\
\hline OPA12 & 0,73 & 2 \\
\hline OPR14 & 0,73 & 3 \\
\hline OPX11 & 0,73 & 2 \\
\hline OPA17 & 0,77 & 3 \\
\hline OPA03 & 0,78 & 3 \\
\hline OPC02 & 0,78 & 3 \\
\hline OPA05 & 0,79 & 3 \\
\hline OPA15 & 0,81 & 3 \\
\hline OPB10 & 0,81 & 3 \\
\hline OPA14 & 0,82 & 4 \\
\hline OPA20 & 0,82 & 3 \\
\hline ОРВ07 & 0,82 & 3 \\
\hline OPA04 & 0,84 & 4 \\
\hline OPA13 & 0,85 & 5 \\
\hline OPAR10 & 0,86 & 4 \\
\hline OPA16 & 0,87 & 5 \\
\hline ОРВ03 & 0,87 & 5 \\
\hline OPAR13 & 0,88 & 5 \\
\hline OPA09 & 0,89 & 6 \\
\hline OPAR20 & 0,89 & 5 \\
\hline ОРВ09 & 0,90 & 7 \\
\hline ОРВ02 & 0,91 & 7 \\
\hline OPB06 & 0,95 & 15 \\
\hline
\end{tabular}




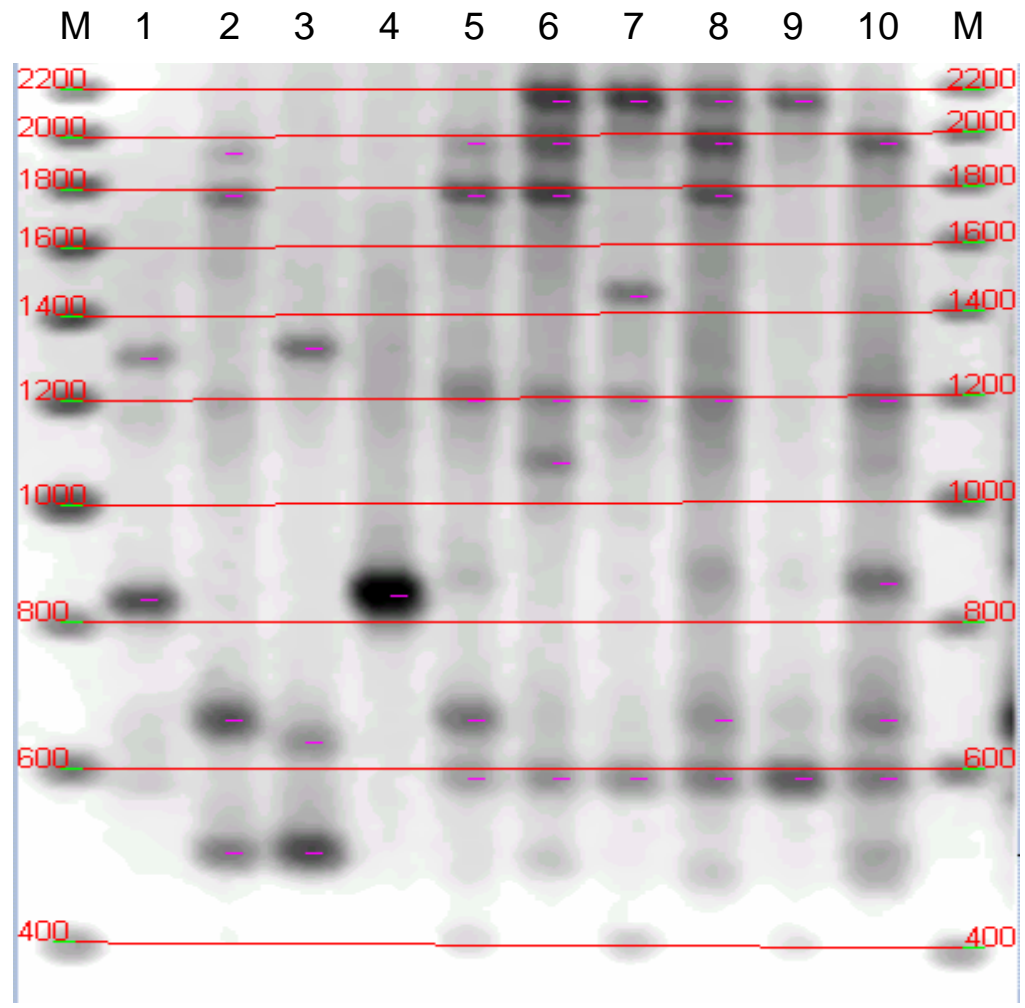

FIGURE 1 - RAPD patterns of elephantgrass accessions generated by primer OPA-17. Lanes: (M) 200 bp step ladder; (1) Cameroon; (2) Mineiro; (3) Vruckwona; (4) Mott; (5) Napier; (6) Pioneiro; (7) Mercker comum; (8) CNPGL 27-5; (9) Teresópolis; (10) Roxo Anão; (M) 200 bp step ladder.

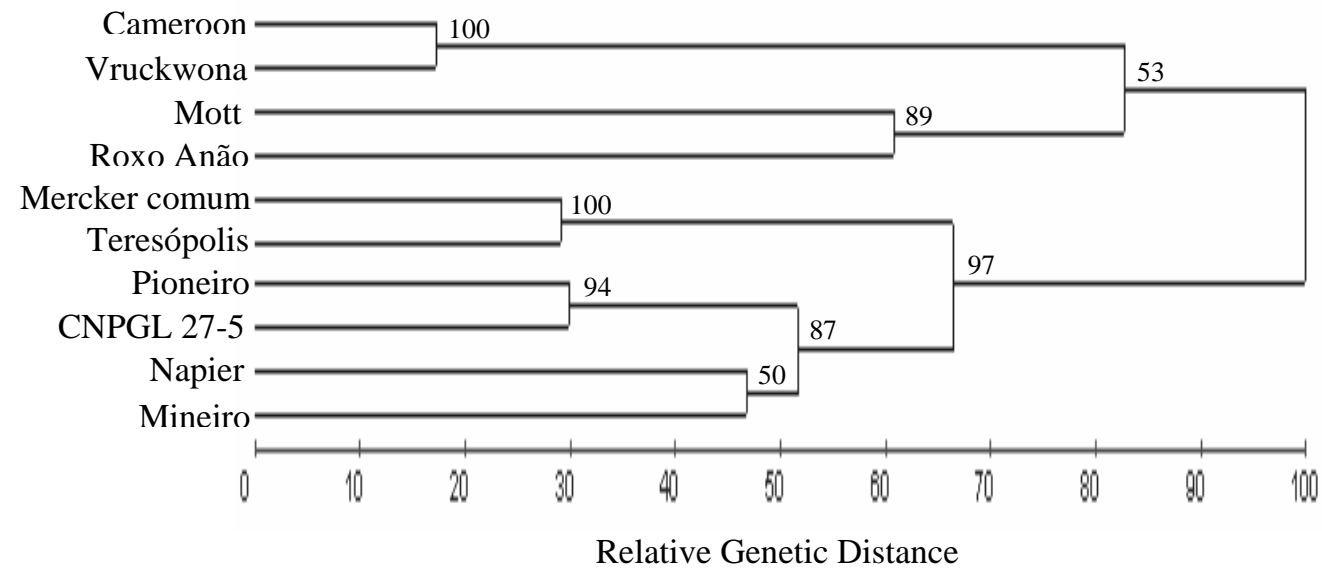

FIGURE 2 - Dendrogram showing 10 elephantgrass accessions based on Nei's genetic distance using UPGMA method and RAPD markers. Numbers at branch points represent bootstrap values with 500 replicates. 
PASSOS, L. P. et al.

TABLE 2 - Nei's genetic distance matrix of 10 accessions of elephantgrass based on RAPD analysis.

\begin{tabular}{|c|c|c|c|c|c|c|c|c|c|c|}
\hline & 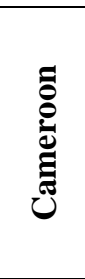 & 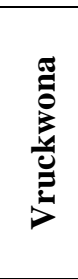 & 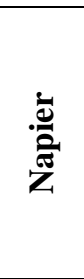 & 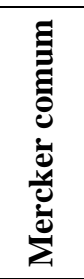 & 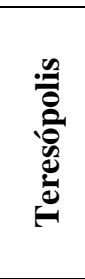 & . & $\sum_{\Sigma}^{ \pm}$ & 串 & $\begin{array}{l}\text { م } \\
\text { N } \\
\text { 先 } \\
\text { 艺 }\end{array}$ & 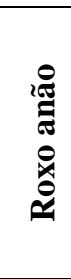 \\
\hline Cameroon & 0,00 & 0,06 & 0,40 & 0,43 & 0,38 & 0,43 & 0,30 & 0,38 & 0,36 & 0,28 \\
\hline Vruckwona & 0,06 & 0,00 & 0,40 & 0,43 & 0,40 & 0,43 & 0,32 & 0,39 & 0,36 & 0,30 \\
\hline Napier & 0,40 & 0,40 & 0,00 & 0,20 & 0,21 & 0,16 & 0,29 & 0,16 & 0,17 & 0,31 \\
\hline Mercker comum & 0,43 & 0,43 & 0,20 & 0,00 & 0,10 & 0,22 & 0,30 & 0,23 & 0,27 & 0,37 \\
\hline Teresópolis & 0,38 & 0,40 & 0,21 & 0,10 & 0,00 & 0,23 & 0,26 & 0,21 & 0,25 & 0,31 \\
\hline Mineiro & 0,43 & 0,43 & 0,16 & 0,22 & 0,23 & 0,00 & 0,33 & 0,16 & 0,22 & 0,34 \\
\hline Mott & 0,30 & 0,32 & 0,29 & 0,30 & 0,26 & 0,33 & 0,00 & 0,29 & 0,29 & 0,22 \\
\hline Pioneiro & 0,38 & 0,39 & 0,16 & 0,23 & 0,21 & 0,16 & 0,29 & 0,00 & 0,10 & 0,30 \\
\hline CNPGL 27-5 & 0,36 & 0,36 & 0,17 & 0,27 & 0,25 & 0,22 & 0,29 & 0,10 & 0,00 & 0,25 \\
\hline Roxo anão & 0,28 & 0,30 & 0,31 & 0,37 & 0,31 & 0,34 & 0,22 & 0,30 & 0,25 & 0,00 \\
\hline Average & 0,34 & 0,34 & 0,26 & 0,28 & 0,26 & 0,28 & 0,29 & 0,25 & 0,25 & 0,30 \\
\hline
\end{tabular}

Accessions Mercker comum and Teresópolis also grouped close together as well as accessions Pioneiro and CNPGL 27-5. Four distinct groups are formed considering a relative genetic distance of 65 . First group formed by accessions Cameroon and Vruckwona; second group formed by accessions Mott and Roxo Anão; third group formed by accessions Mercker comum and Teresópolis and fourth group formed by accessions Pioneiro, CNPGL 27-5, Napier and Mineiro. All groups showed high bootstrap values, ranging from 87 to 100 .

Results are in agreement with RAPD-based work on the genetic diversity of other species reported elsewhere. Martin et al. (1995) examined the relationship among seven wheat cultivars through PCR profiles and concluded that the degree of genetic variability among parents was not an adequate measure for predicting heterosis in the species. Gustafson et al. (1999) characterized genetic diversity and genetic distinctiveness of big bluestem grass with the purpose of assessing genetic erosion. Nietsche et al. (2001) identified thirteen races of the common bean pathogen Phaeoisariopsis griseola and mapped their origin.

\section{CONCLUSIONS}

The genetic distance data obtained in this study might be useful as an auxiliary tool in future strategies for crossings and diallel elaboration, so as to evaluate general and specific combination capabilities of desired genotypes. Such molecular data would be also useful for detecting DNA patterns unique for a given accession or set of accessions, which would be utilized as a descriptor with right protection purposes. Finally, our findings demonstrate the feasibility of the RAPD technique for quantifying genetic distances among elephantgrass accessions, although suggesting an overall need for further work with a greater number of genotypes for a better understanding of the genetic variability of the species.

\section{REFERENCES}

BIRMETA, G.; NYBOM, H.; BEKELE, E. Distinction between wild and cultivated enset (Ensete ventricosum) gene pools in Ethiopia using RAPD markers. Hereditas, [S.l.], v. 140, p. 139-148, 2004.

COELHO, A. S. G. BOOD-P: evaluation of dendrograms based on genetic distances/similarities estimates through bootstrap. v. 3.0. Goiânia: UFGO, 2003. 
CONGIU, L.; CHICCA, R.; CELLA, R. The use of random amplified polymorphic DNA (RAPD) markers to identify strawberry varieties: a forensic application. Molecular Ecology, Loughborough, v. 9, p. 229-232, 2000.

FERREIRA, M. E.; GRATTAPAGLIA, D. Introdução ao uso de marcadores moleculares em análise genética. 2. ed. Brasília: EMBRAPA, 1995. 220 p.

GUSTAFSON, D. J.; GIBSON, J.; NICKRENT, D. L. Random amplified polymorphic DNA variation among remnant big bluestem (Andropogon gerardii Vitman) populations from Arkansas' Grand Prairie. Molecular Ecology, Loughborough, v. 8, p. 16931701, 1999.

HANNA, W. W. Melhoramento do capim-elefante. In: PASSOS, L. P.; CARVALHO, L. de A.; MARTINS, C. E. Biologia e manejo do capim-elefante. Juiz de Fora: EMBRAPA Gado de Leite, 1999. p. 17-27.

HAO, Y. J.; WEN, X. P.; DENG, X. X. Genetic and epigenetic evaluations of citrus calluses recovered from slow-growth culture. Journal of Plant Physiology, Stuttgart, v. 161, p. 479-484, 2004.

HOSOKAWA, K.; MINAMI, M.; KAWAHARA, K. Discrimination among three species of medicinal Scutellaria plants using RAPD markers. Planta Medica, Stuttgart, v. 66, p. 270-272, 2000.

LAIA, M. L. de; GOMES, E. A.; ESBRISSE, E. J. Random amplified polymorphic DNA (RAPD) analysis of genotypic identities in Eucalyptus clones. Silvae Genetica, Hamburg, v. 49, p. 239-243, 2000.

MARTIN, J. M.; TALBERT, L. E.; BLAKE, N. K.; LANNING, S. P. Hybrid performance in wheat as related to parental diversity. Crop Science, Madison, v. 35, p. 104-108, 1995.

NEI, M.; LI, W. H. Mathematical model for studying genetic variation in terms of restriction endonucleases. Proceedings of the National Academy of Sciences U.S.A., Washington, v. 76, p. 5269-5273, 1979.

NIETSCHE, S.; BORÉM, A.; CARVALHOS, G. A. de. Genetic diversity of Phaeoisariopsis griseola in the State of Minas Gerais, Brazil. Euphytica, Wageningen, v. 117, p. 77-84, 2001.
PASSOS, L. P. Fisiologia do capim-elefante: uma revisão analítica. In: PASSOS, L. P.; CARVALHO, L. de A.; MARTINS, C. E. Biologia e manejo do capim-elefante. Juiz de Fora: EMBRAPA-CNPGL, 1999. p. 29-62.

PEREIRA, A. V.; VALLE, C. B. do; FERREIRA, R. de P. Melhoramento de forrageiras tropicais. In: NASS, L. L.; VALOIS, A. C. C.; MELO, I. S. de. Recursos genéticos e melhoramento de plantas. Rondonópolis: Fundação de Apoio à Pesquisa Agropecuária do Mato Grosso, 2001. p. 549-601.

SALVI, N. D.; GEORGE, L.; EAPEN, S. Micropropagation and field evaluation of micropropagated plants of turmeric. Plant Cell, Tissue and Organ Culture, Dordrecht, v. 68, p. 143-151, 2002.

SGORBATI, S.; LABRA, M.; GRUGNI, E.; BARCACCIA, G.; GALASSO, G.; BONI, U.; MUCCIARELLI, M.; CITTERIO, S.; BENAVIDES IRAMATEGUI, A.; VENERO GONZALES, L.; SCANNERINI, S. A survey of genetic diversity and reproductive biology of Puya raimondii (Bromeliaceae), the endangered queen of the Andes. Plant Biology, Stuttgart, v. 6, p. 222-230, 2004.

SHENOY, V. B.; VASIL, I. K. Biochemical and molecular analysis of plants derived from embryogenic tissue cultures of napier grass (Pennisetum purpureum K. Schum). Theoretical and Applied Genetics, Berlin, v. 83, p. 947-955, 1992.

SMITH, R. L.; CHOWDHURY, M. K. U.; SCHANK, S. C. Use of restriction fragment-length polymorphism (RFLP) markers in genetics and breeding of napier grass. Soil and Crop Science Society of Florida Proceedings, Boca Raton, v. 48, p. 13-19, 1989.

SONNANTE, G.; PAOLIS, A. de; LATTANZIO, V. Genetic variation in wild and cultivated artichoke revealed by RAPD markers. Genetic Resources and Crop Evolution, Dordrecht, v. 49, p. 247-252, 2002.

TSUJI, K.; OHNISHI, O. Phylogenetic position of east Tibetan natural populations in Tartary buckwheat (Fagopyrum tataricum Gaert.) revealed by RAPD analyses. Genetic Resources and Crop Evolution, Dordrecht, v. 48, p. 63-67, 2001. 
VICCINI, L. F.; COSTA, D. C. S.; MACHADO, M. A.; XAVIER, D.; BOTREL, M. de A.; DAHER, R. F. CAMPOS, A. L. Genetic diversity among nine species Caracterização morfológica e agronômica de of Lippia (Verbanaceae) based on RAPD Markers. algumas variedades de capim-elefante. Juiz de Fora: Plant Systematics and Evolution, [S.l.], v. 246, p. 1-8, EMBRAPA Gado de Leite, 1995. 24 p. (Documentos, 2004. $60)$.

Ciênc. agrotec., Lavras, v. 29, n. 3, p. 568-574, maio/jun., 2005 